\title{
Nasal Carriage of Staphylococcus aureus and MRSA among Companion Animals and Livestock in Wayanad District, India
}

\author{
Hamna Hakim $^{2 *}$, Prejit ${ }^{1,2}$, K. Asha ${ }^{2}$, Jess Vergis ${ }^{1,2}$, P. M. Deepa ${ }^{3}$, \\ N. Suma ${ }^{2}$ and Hema Persis Andrews ${ }^{2}$
}

${ }^{1}$ Centre for One Health Education, Advocacy, Research and Training

${ }^{2}$ Department of Veterinary Public Health, CV\&AS, Pookode, India ${ }^{3}$ Department of Veterinary Preventive Medicine and Epidemiology, CV\&AS, Pookode Kerala Veterinary and Animal Sciences University, Pookode, Wayanad-673576, India

*Corresponding author

\section{A B S T R A C T}

\section{Keywords}

Cefoxitin,

Oxacillin, Dogs

(30), Cats (30),

Cattle (40), Goats

(30), Multi-drug

resistance

Article Info

Accepted:

12 November 2019

Available Online:

10 December 2019
Antimicrobial resistance (AMR) is one of the leading threats in healthcare management system. Staphylococcus aureus is a commensal bacteria commonly seen on skin and nasal passage that can turn as an opportunistic pathogen. The present study was carried out to evaluate the nasal carriage of $S$. aureus and methicillinresistant $S$. aureus (MRSA) among apparently healthy companion animals and livestock. A total of 160 nasal swabs were collected from dogs (30), cats (30), cattle (40), goats (30), and pigs (30). All the samples were initially screened for prevalence of $S$. aureus, which was confirmed by PCR using species specific primer (nuc gene). All the $S$. aureus isolates were screened for occurrence of MRSA, both phenotypically (by double disc diffusion using cefoxitin and oxacillin discs) and genotypically (by PCR targeting mecA gene). There was significant difference in nasal carriage of $S$. aureus among animal population (Chi-square value -33.206 , p-value $<0.001$ ), which was found as 76.67 per cent, 23.33 per cent, 53.33 per cent, 62.5 per cent, and 86.67 per cent among dogs, cats, cattle, goats, and pigs respectively. None of the nasal swabs from animals were positive for MRSA. The present study signifies the occurrence of nasal carriage of $S$. aureus and absence of MRSA among domestic animal population of Wayanad district.

\section{Introduction}

Bacteria remain the most enduring life forms on earth that has developed various mechanisms to surpass adversities. Through the advancement in medicine, antibiotics were discovered to counteract bacterial infections. However, multi-drug resistance (MDR) is now an emerging issue in the management of such infections and Staphylococcus aureus is a predominant pathogen that has developed resistance to antibiotics. $S$. aureus is a 
commensal bacteria that is found on skin and nasal passage which has the potential to become an opportunistic pathogen. The primary habitat of $S$. aureus is the anterior nares (Foster, 2009). S. aureus nasal colonization increases the risk of autoinfection. Clonal spread of MRSA between man and pigs was reported in Netherlands (Huijsdens et al., 2006). Researchers across the globe validated the occurrence and significance of $S$. aureus and MRSA by way of nasal carriage. However, such reports are scarce in Kerala especially in Wayanad district that borders Tamil Nadu and Karnataka. Thus, the present study was aimed at finding the nasal carriage of $S$. aureus and MRSA among apparently healthy companion animals (dogs and cats) and livestock (cattle, goats, and pigs) in Wayanad district.

\section{Materials and Methods}

The nasal swabs were collected from 160 apparently healthy animals comprising of dogs (30), cats (30), cattle (40), goats (30), and pigs (30). A sterile cotton swab moistened with normal saline was inserted into nares and gently rotated to make contact with the nasal septum. The nasal swabs were transported to the laboratory in sterile polypropylene tubes containing Cary-Blair transport medium using sterile cotton swabs, under chilled condition. The samples were processed in laboratory for isolation and molecular detection of $S$. aureus and MRSA. All the samples were enriched in the selective enrichment broth (Tryptone soya broth with 10 per cent $\mathrm{NaCl}$ ), followed by streaking onto Baird Parker selective agar and thereafter, confirmed by biochemical test as described by Barrow and Feltham (2003) and Agarwal et al., (2003). Characteristic colonies of $S$. aureus were further confirmed by PCR using species specific primer for nuc gene. Phenotypic identification of MRSA is done by oxacillin and cefoxitin double disc diffusion method (Bauer et al., 1966). All the S. aureus positive isolates were screened for MRSA by using primers for mecA gene (Vannuffelet al., 1995). The primer details and cycling conditions for various genes (nис, mecA) used in the study are detailed in Table 1 and 2.

\section{Results and Discussion}

\section{Isolation of $S$. aureus by culture method}

Greyish black colonies with a halo zone around were characteristic of S. aureus (Fig. $1)$. These colonies might be confused with other Staphylococci spp. (Baird and Lee, 1995). Hence, further confirmation of the characteristic colonies was done by biochemical identification and is shown in Table 3. Out of the total 160 samples screened, 142 isolates gave characteristic growth on BP agar. Upon biochemical analysis, out of all the 142 positive isolates from BP agar, S. aureus was confirmed from nasal swabs of 97 animals.

\section{PCR confirmation of isolates as $S$. aureus}

The suspected S. aureus isolates from BP agar were precisely identified by PCR using species specific primer targeting nuc gene (Fig. 2). The PCR for amplification of the nuc gene has potential for the rapid diagnosis of $S$. aureus (Brakstad et al., 1995). The occurrence of $S$. aureus was thus confirmed in 97 isolates out of the 142 suspected isolates from BP agar.

\section{Occurrence of $S$. aureus among dogs}

Out of the 30 dog nasal swabs screened, 23 samples were positive for $S$. aureus, which included seven isolates from Mananthavady taluk and eight each from Sulthan Bathery and Vythiri taluks (Table 4). Thus, an overall occurrence of 76.67 per cent among dogs of Wayanad district was observed. Krogh and Kristensen (1976) reported occurrence of $S$. 
aureus among 90 per cent of the dogs screened. Ma et al., (2019) reported from New South Wales, Australia that 67.3 per cent of dogs carried at least one species of Staphylococcus organisms.

\section{Occurrence of $S$. aureus among cats}

A total of seven out of 30 (23.33 per cent) cats sampled from Wayanad district was positive for nasal carriage of $S$. aureus. Among seven positive cats, two were from Sulthan Bathery, three from Mananthavady and two from Vythiri Taluk and is shown in Table 4. Cats were among the least occurrence group from different species of animals studied. Ma et al., (2019) reported 73.8 per cent of cats carried at least one species of Staphylococcus in New South Wales, Australia. Krogh and Kristensen (1976) reported $S$. aureus in 40 per cent of the cats. Nasal colonization of pet cats is significant due to the close interaction of cats within the households.

\section{Occurrence of $S$. aureus among cattle}

Among a total of 40 nasal swabs were analysed from cattle and 25 isolates were positive for $S$. aureus nasal carriage which included ten from Sulthan Bathery, nine from Mananthavady and six from Vythiri taluk (Table 4). This accounts to 62.50 per cent overall occurrence of the organism among cattle in Wayanad district. This finding was much higher when compared to 14.1 per cent occurrence of $S$. aureus in cattle as reported by Rahimi et al., (2015) and 22 per cent reported by Alzohairy (2011).

\section{Occurrence of $S$. aureus among goats}

A total of 16 out of 30 (53.33 per cent) goats that were screened showed positive for nasal carriage of $S$. aureus. Among the positive samples, seven were from Sulthan Bathery, six from Mananthavady and three were from Vythiri. Rahimi et al., (2015) reported that in contrast to cattle, $S$. aureus was frequently present in the nose of sheep and goats. But the present study showed lower occurrence of $S$. aureus in goats as compared to cattle.

\section{Occurrence of $S$. aureus among pigs}

Pigs had the highest occurrence of nasal carriage of $S$. aureus when compared to other animal groups in the study. A total of 26 out of the 30 pigs screened confirmed for $S$. aureus nasal carriage, and it included eight from Sulthan Bathery, nine from Mananthavady and nine from Vythiri. A high rate of $S$. aureus strain exchange between pigs and farmers was confirmed by ArmandLefevre et al., (2005).

Table.1 Details of oligonucleotides used in the study

\begin{tabular}{|c|c|c|c|c|}
\hline SL.NO. & $\begin{array}{l}\text { PRIM } \\
\text { ER }\end{array}$ & SEQUENCE (5' - 3') & $\begin{array}{c}\text { AMPLIC } \\
\text { ON SIZE } \\
\text { (bp) }\end{array}$ & $\begin{array}{c}\text { REFERENC } \\
\text { ES }\end{array}$ \\
\hline \multirow[t]{2}{*}{1} & \multirow[t]{2}{*}{ nuc } & F : GCGATTGATGGGTGATACGGTT & \multirow[t]{2}{*}{267} & \multirow{2}{*}{$\begin{array}{l}\text { Brakstad et } \\
\text { al., (1992) }\end{array}$} \\
\hline & & R: AGCCAAGCCTTGACGAACTAAAGC & & \\
\hline \multirow[t]{3}{*}{2} & \multirow[t]{3}{*}{ mecA } & F : AAAATCGATGGTAAAGGTTGGC & \multirow[t]{3}{*}{533} & \multirow{3}{*}{$\begin{array}{l}\text { Vannuffel et } \\
\text { al., (1995) }\end{array}$} \\
\hline & & R : GTTCTGCAGTACCGGATTTGC & & \\
\hline & & R : CAGCAGTAGTGCCGTTTGCTT & & \\
\hline
\end{tabular}


Table.2 Temperature and various cyclic conditions for PCR

\begin{tabular}{|c|c|c|c|}
\hline \multirow[t]{2}{*}{ STEPS } & \multicolumn{2}{|c|}{ CONDITIONS FOR THE PRIMER } & \multirow{2}{*}{$\begin{array}{l}\text { NO.OF } \\
\text { CYCLES }\end{array}$} \\
\hline & nuc primer & mecA primer & \\
\hline $\begin{array}{c}\text { Initial } \\
\text { denaturation }\end{array}$ & $94 \circ \mathrm{C}$ for $5 \mathrm{~min}$. & $94{ }^{\circ} \mathrm{C}$ for $5 \mathrm{~min}$. & \\
\hline Denaturation & $94 \circ \mathrm{C}$ for $30 \mathrm{sec}$. & $94 \circ \mathrm{C}$ for $30 \mathrm{sec}$. & \multirow{3}{*}{35 cycles } \\
\hline Annealing & $58{ }^{\circ} \mathrm{C}$ for $40 \mathrm{sec}$. & $57 \circ \mathrm{C}$ for $40 \mathrm{sec}$. & \\
\hline Extension & $72 \circ \mathrm{C}$ for $60 \mathrm{sec}$. & $72 \circ \mathrm{C}$ for $60 \mathrm{sec}$. & \\
\hline Final extension & $72 \circ \mathrm{C}$ for $5 \mathrm{~min}$. & $72 \circ \mathrm{C}$ for $5 \mathrm{~min}$. & \\
\hline
\end{tabular}

Table.3 Biochemical tests for $S$. aureus

\begin{tabular}{|c|c|c|}
\hline SL.NO & Biochemical test & \multicolumn{1}{|c|}{ Test reaction } \\
\hline $\mathbf{1}$ & Grams staining & $\begin{array}{c}\text { Gram +, Cocci, single, pair, } \\
\text { cluster or bunch of grapes }\end{array}$ \\
\hline $\mathbf{2}$ & Catalase test & Positive \\
\hline $\mathbf{3}$ & Voges Proskauer test & Positive \\
\hline $\mathbf{4}$ & Oxidase test & Negative \\
\hline $\mathbf{5}$ & Coagulase test & Positive \\
\hline $\mathbf{6}$ & Arginine hydrolysis & Positive \\
\hline $\mathbf{7}$ & Sugar fermentation reactions (Lactose, \\
& Glucose, Maltose, Sucrose) & Positive \\
\hline
\end{tabular}

Table.4 Occurrence of $S$. aureus among animals

\begin{tabular}{|c|c|c|c|}
\hline Species & $\begin{array}{c}\text { No:of nasal } \\
\text { swabs }\end{array}$ & $\begin{array}{c}\text { S. aureus isolates } \\
\text { obtained }\end{array}$ & $\begin{array}{c}\text { Occurrence of } \mathbf{S} \\
\text { aureus } \text { (per cent) }\end{array}$ \\
\hline Dog & 30 & 23 & $76.67^{\mathrm{a}}{ }^{\mathrm{d}}$ \\
\hline Cat & 30 & 7 & $23.33^{\mathrm{bc}}$ \\
\hline Cattle & 40 & 25 & $62.50^{\mathrm{c}}$ \\
\hline Goat & 30 & 16 & $53.33^{\mathrm{c}}$ \\
\hline Pig & 30 & $26^{\mathrm{a}}$ & $86.67^{\mathrm{C}}$ \\
\hline
\end{tabular}


Fig.1 Baird parker agar with greyish black colonies with a halo around, characteristic of $S$. aureus

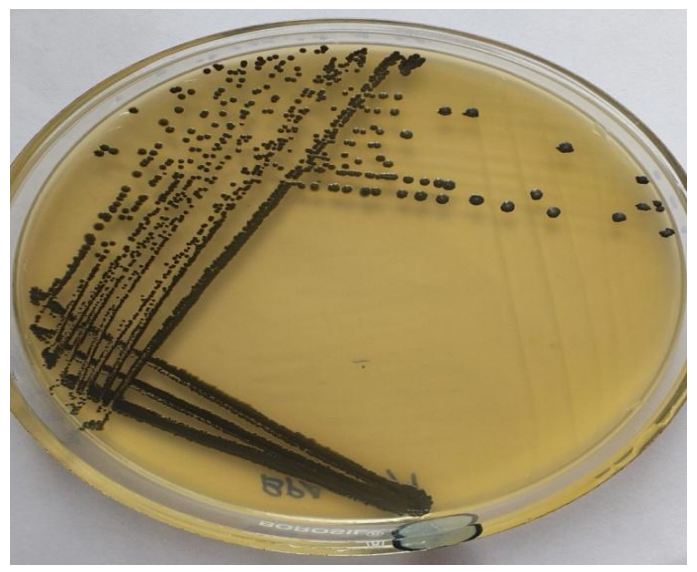

Fig.2 PCR standardisation of nuc gene. Lane 1 - Marker, Lane 2,3 - nuc positive samples of amplicon size 275 bp, Lane 4 - Negative control, Lane 5 - Positive control

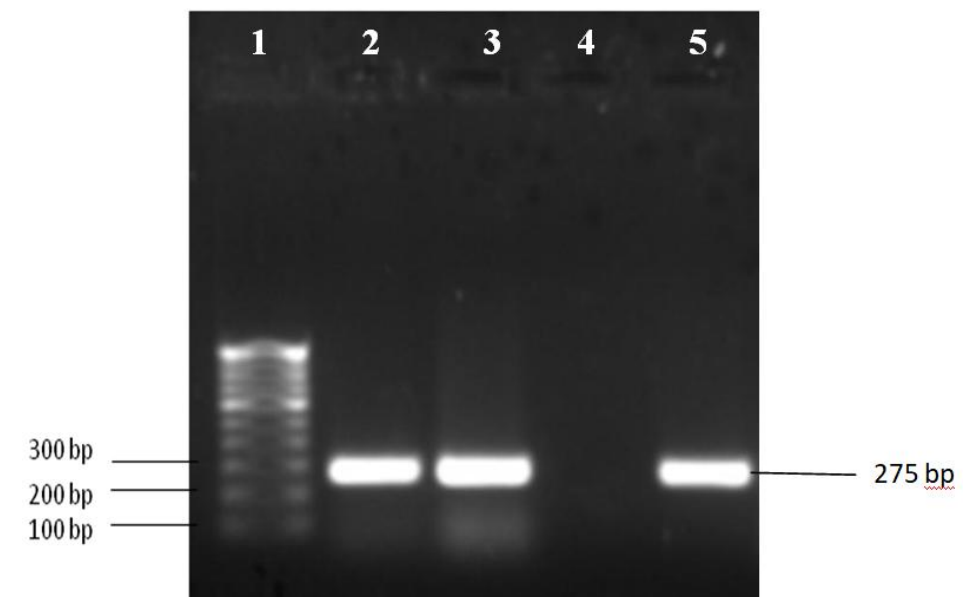

Fig.3 Cefoxitin and Oxacillinsuscetible (MSSA) strain of S. aureus on Muller Hinton agar

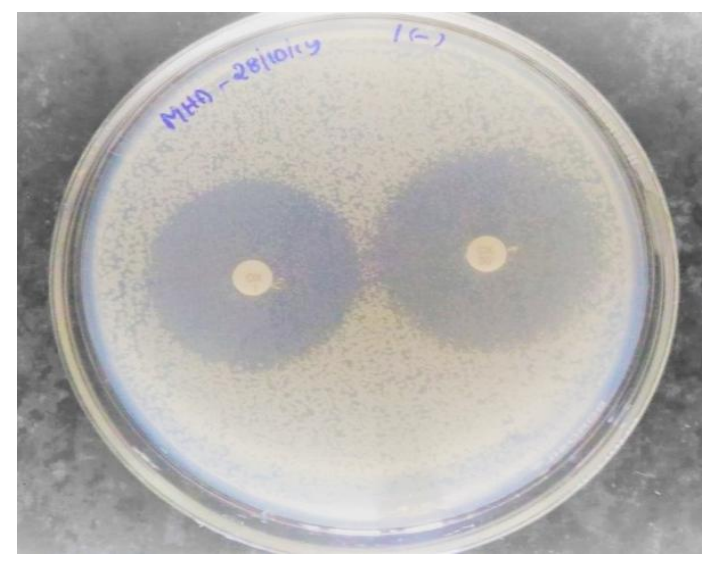


Fig.4 PCR Standardization of mecA gene. Lane 1- Marker, Lane 2,3 - mecA positive samples with amplicon size 533 bp, Lane 4- Negative control, Lane 5- Positive control

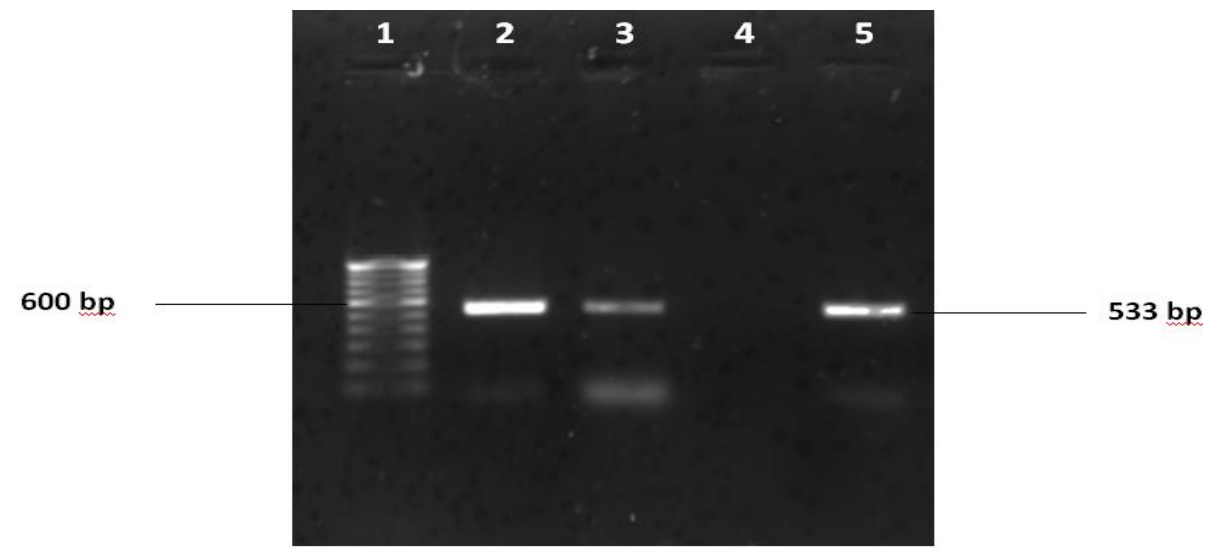

Statistical analysis of occurrence of $S$. aureus among animals

The statistical analysis of occurrence of $S$. aureus was performed using Chi-square test for multiple proportions followed by pair-wise comparison using $\mathrm{z}$-test for testing two proportion between different groups of animals. There existed significant difference between dogs, cats, and goats. There was no significant difference between dogs and pigs. Between Goats and cattle also no significant difference was observed.

\section{Occurrence of MRSA among the animal population}

MRSA was phenotypically identified by double disc diffusion test using oxacillin and cefoxitin. However, none of the $S$. aureus isolates in the study gave the typical resistance pattern to Cefoxitin and Oxacillin, indicating that they were sensitive to these drugs (Fig. 3).

All the $S$. aureus isolates were screened for presence of mecA gene to confirm MRSA. PCR standardization for mecA gene was done using known positive DNA (Fig. 4), which yielded product of size $533 \mathrm{bp}$. None of the isolates were positive for $m e c A$ gene.
Thus, it was concluded that no MRSA was found from nasal swabs of dogs, cats, cattle, goats, and pigs. Hence from the present study zero per cent occurrence of MRSA from nasal swab of companion animals- dogs and cats, and livestock- cattle, goats and pigs was observed. The pooled prevalence of MRSA in animals in India was found to be 10 per cent which is lower than that of MRSA prevalence in humans (Krishnamoorthy et al., 2019). The present study result of zero per cent occurrence among dogs correlated with Ma $e t$ al., (2019), who reported an absence of MRSA among cats in New South Wales, Australia.

There is significantly higher nasal carriage of $S$. aureus among apparently healthy companion animals (dogs and cats) and livestock (cattle, goats and pigs) of Wayanad district. The study also observed absence of MRSA nasal colonization among domestic animal population, which gives a transient relief to human and animal medical practitioners as there are increasing reports of MRSA burden from apparently healthy animals around the globe.

\section{References}

Agarwal, R.K., Bhilegaonkar, K.N., Singh, D. K., Ashok, K. and Rathore, R.S. 
2003.In: Laboratory manual for the isolation and identification of food bornepathogens. Indian Veterinary Research Institute, Izatnagar, Bareilly, India, 100p.

Alzohairy, M.A., 2011. Colonization and antibiotic susceptibility pattern of methicillin resistance Staphylococcus aureus (MRSA) among farm animals in Saudi Arabia. Afr. J. Bacteriol. Res. 3: 63-68.

Armand-Lefevre, L., Ruimy, R. and Andremont, A. 2005. Clonal comparison of Staphylococcus aureus isolates from healthy pig farmers, human controls, and pigs. Emerging infect. Dis. 11: 711.

Baird, R.M. and Lee, W.H. 1995. Media used in the detection and enumeration of Staphylococcus aureus. Int. J. Food Microbiol. 26: 15-24.

Barrow, G.I. and Feltham, R.K.A. 2003. Cowan and Steel's Manual for Identification of Medical Bacteria. $\left(3^{\text {rd }} \mathrm{Ed}\right)$ Cambridge press. 331p.

Brakstad, O.G., Aasbakk, K. and Maeland, J.A. 1992. Detection of Staphylococcus aureus by polymerase chain reaction amplification of the nuc gene. J. Clin. Microbiol. 30: 1654-1660.

Foster, T.J. 2009. Colonization and infection of the human host by staphylococci: adhesion, survival and immune evasion. Vet. Dermatol. 20: 456-470.

Huijsdens, X.W., Van Dijke, B.J., Spalburg, E., van Santen-Verheuvel, M.G., Heck, M.E., Pluister, G.N., Voss, A., Wannet, W.J. and De Neeling, A.J. 2006. Community-acquired MRSA and pigfarming. Ann. Clin. Microbial. Antimicrob. 5: 26.
Huijsdens, X.W., Van Dijke, B.J., Spalburg, E., van Santen-Verheuvel, M.G., Heck, M.E., Pluister, G.N., Voss, A., Wannet, W.J. and De Neeling, A.J. 2006. Community-acquired MRSA and pigfarming. Ann. Clin. Microbial. Antimicrob. 5: 26.

Krishnamoorthy, P., Hamsapriya, S., Ashwini, M., Patil, S.S., Roy, P. and Suresh, K.P. 2019. Systematic Review and MetaAnalysis of Livestock AssociatedMethicillin Resistant Staphylococcus aureus (LA-MRSA) Prevalence in Animals in India. Int. J. Livestock Res. 9 : 179-191.

Krogh, H.V. and Kristensen, S. 1976. A study of skin diseases in dogs and cats. II. Microflora of the normal skin of dogs and cats. Nordisk Veterinaer. Medicin. 28: 459-463.

Ma, G.C., Worthing, K.A., Ward, M.P. and Norris, J.M. 2019. Commensal Staphylococci Including MethicillinResistant Staphylococcus aureus from Dogs and Cats in Remote New South Wales, Australia. Microbial ecology. 1: 11.

Rahimi, H., Saei, H.D. and Ahmadi, M. 2015. Nasal carriage of Staphylococcus aureus: Frequency and antibiotic resistance in healthy ruminants. Jundishapur J. Microbiol. 8: 10.

Vannuffel, P., Gigi, J., Ezzedine, H., Vandercam, B., Delmee, M., Wauters, G. and Gala, J. L. 1995. Specific detection of methicillin-resistant Staphylococcus species by multiplex PCR. J. Clin. Microbiol. 33: 28642867.

\section{How to cite this article:}

Hamna Hakim, Prejit, K. Asha, Jess Vergis, P. M. Deepa, N. Suma and Hema Persis Andrews. 2019. Nasal Carriage of Staphylococcus aureus and MRSA among Companion Animals and Livestock in Wayanad District. Int.J.Curr.Microbiol.App.Sci. 8(12): 1254-1260. doi: https://doi.org/10.20546/ijcmas.2019.812.155 